\title{
A circus postcard showing short statue in a clown and a horse
}

\author{
W. W. de $\operatorname{Herder}^{1}$ (D)
}

Received: 12 July 2021 / Accepted: 27 July 2021 / Published online: 7 August 2021

(c) The Author(s) 2021

Keywords Achondroplasia $\cdot$ Circus $\cdot$ Short stature $\cdot$ Horse

\begin{abstract}
A picture postcard of the German Zirkus Busch (the Busch Circus) dating 1905-6 titled: "Das Dackelpferd im Circus Bush" = "The dachshund-shaped horse in circus Bush" showing a male with typical achondroplasia dressed as a clown and a dysmorphic Friesian horse with short limbs (Fig. 1).

The famous German Bush Circus was founded in 1884 by Paul Vinzenz Theodor Busch (1850-1927). It was a travelling circus with its main circus building, which could hold up to 4300 spectators, established in Berlin in 1895.
\end{abstract}

Achondroplasia is the most common cause of short statue in humans and affects about 1 in 25,000 people. Achondroplasia is inherited as an autosomal dominant trait. However, about $80 \%$ of cases result from a de novo mutation. It is caused by gain-of-function variant in the FGFR3 gene. Its predominant phenotype is: disproportionate short stature with rhizomelic shortening of the arms and the legs, brachydactyly, kyphoscoliosis and accentuated lumbar lordosis, macrocephaly, frontal bossing, midface retrusion, and saddle nose deformity.

In Friesian horses, short statue is characterized by the limbs being $25 \%$ shorter than normal and growth retardation of the ribs. Usually, the head and back grow faster than the limbs and ribs giving these horses the characteristic disproportional appearance. Furthermore, their bodyweight is

W. W. de Herder

w.w.deherder@erasmusmc.nl

1 Department of Internal Medicine, Sector of Endocrinology,

Rg520, Erasmus MC, Dr. Molewaterplein 40,

3015 GD Rotterdam, The Netherlands 
Fig. 1 Das Dackelpferd im Circus Bush (1906). Picture from the collection of W.W. de Herder

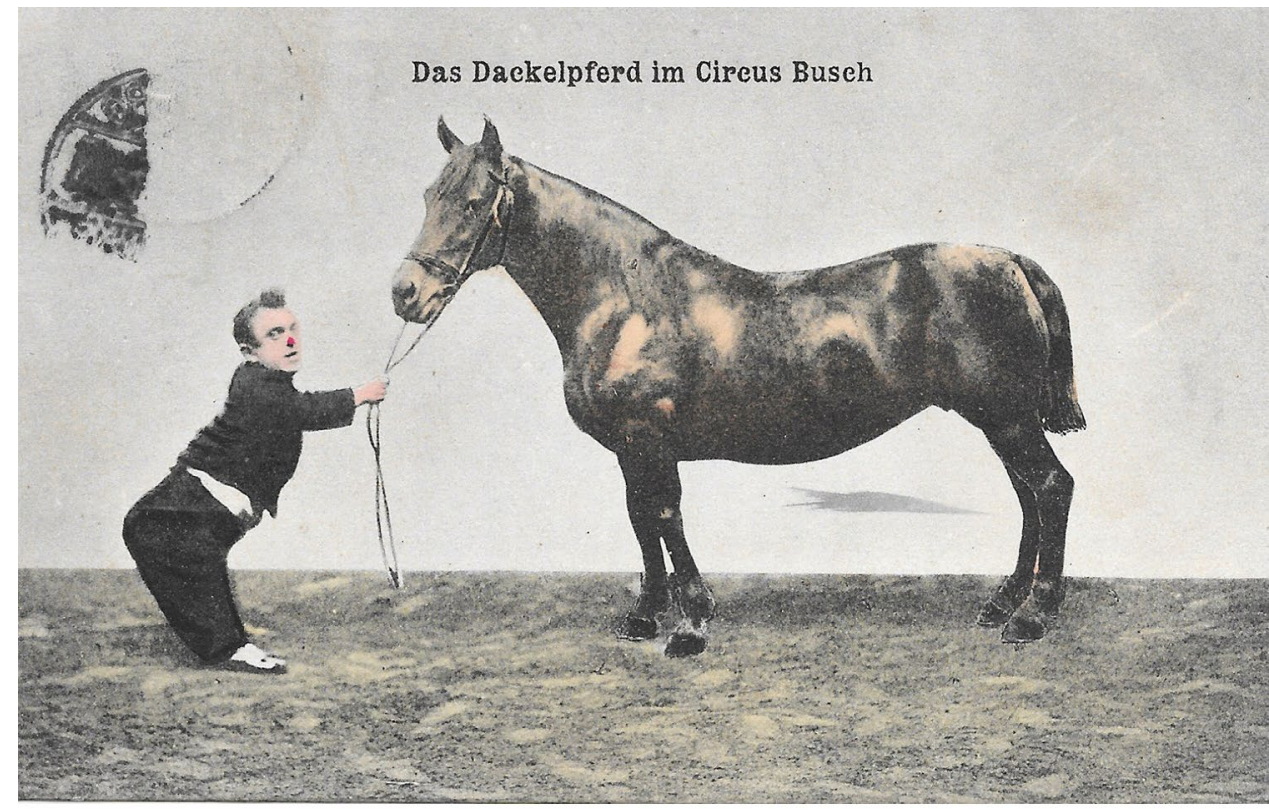

Das Dackelpferd im Circus Bush (1906) reduced by $50 \%$. The estimated incidence of this disorder is 1:400. It is assumed that this disorder is inherited as an autosomal recessive monogenic trait [1].

Conflicts of interest There are NO potential conflicts of interest.

Research involving human participants and/or animals The study did not involve the participation of humans and/or animals. The study did not require approval of medical ethical committees.

Informed Consent For this type of study formal consent is not required.

Open Access This article is licensed under a Creative Commons Attribution 4.0 International License, which permits use, sharing, adaptation, distribution and reproduction in any medium or format, as long as you give appropriate credit to the original author(s) and the source, provide a link to the Creative Commons licence, and indicate if changes were made. The images or other third party material in this article are included in the article's Creative Commons licence, unless indicated otherwise in a credit line to the material. If material is not included in the article's Creative Commons licence and your intended use is not permitted by statutory regulation or exceeds the permitted use, you will need to obtain permission directly from the copyright holder. To view a copy of this licence, visit http://creativecommons.org/licenses/by/4.0/.

\section{Reference}

1. Back W, van der Lugt JJ, Nikkels PG, van den Belt AJ, van der Kolk JH, Stout TA (2008) Phenotypic diagnosis of dwarfism in six Friesian horses. Equine Vet J 40(3):282-287

Publisher's Note Springer Nature remains neutral with regard to jurisdictional claims in published maps and institutional affiliations. 